\title{
Imagining London: the role of the geographical imagination in migrant subjectivity and decision-making
}

\author{
Daniel Robins
}

\begin{tabular}{|c|c|}
\hline Date of deposit & 09122020 \\
\hline Document version & Author's accepted manuscript \\
\hline Access rights & $\begin{array}{l}\text { (C) } 2018 \text {, Royal Geographical Society (with the Institute of British } \\
\text { Geographers). This work is made available online in accordance } \\
\text { with the publisher's policies. This is the author created, accepted } \\
\text { version manuscript following peer review and may differ slightly } \\
\text { from the final published version. }\end{array}$ \\
\hline $\begin{array}{l}\text { Citation for } \\
\text { published version }\end{array}$ & $\begin{array}{l}\text { Robins, D. (2018). Imagining London: the role of the } \\
\text { geographical imagination in migrant subjectivity and decision- } \\
\text { making. Area, Early View }\end{array}$ \\
\hline $\begin{array}{l}\text { Link to published } \\
\text { version }\end{array}$ & https://doi.org/10.1111/area.12519 \\
\hline
\end{tabular}

Full metadata for this item is available in St Andrews Research

Repository at: https://research-repository.st-andrews.ac.uk/

\section{St Andrews Research Repository}




\title{
THESIS VERSION
}

Imagining London: the role of the geographical imagination in migrant subjectivity and decisionmaking

\begin{abstract}
This article employs a qualitative, biographical approach, to explore the motivations and subjectivities behind migration of middle-class Brazilians to London. It uses the concept of the geographical imagination to understand how migrants imagine not only their destinations and places of origin but also how their own identity is shaped by their imagined relationship to these places. The paper argues that for many middle-class Brazilians, their motivation to migrate is couched in terms of 'societal alienation': a feeling of distance from the place of origin resulting from a lack of identification and trust in its institutions and the very culture of the place itself. This is in contrast to the more popularly understood concept of migrating due to 'material alienation': migrating to access a higher level of material consumption or to acquire financial capital to use 'back home'. For those who migrate due to 'societal alienation' what is 'fetishised' is the cultural and less material aspects of the 'quality of life' of the migration destination, which become a kind of commodity in their own right. It argues that social class which often intersects with regional and racial divisions within Brazilian society, is a key marker of difference in these two types of imaginary.
\end{abstract}

Key Words: Migration, Brazil, London, class, inequality, geographical imagination 


\section{Introduction}

Recent quantitative data (Evans et al. 2015; Carling \& Jolivet 2016) on the Brazilian population of London paints an intriguing picture. It shows there are many who do not socialise with other Brazilians, do not engage in Brazilian cultural and/or leisure activities, claim not to have migrated for economic reasons and instead for the more ephemeral ideal of a 'better quality of life'. Almost three quarters of Carling and Jolivet's interviewees had a positive perception of the economic situation in Brazil. Conversely only half had a positive perception of the economic opportunities available in Western Europe (p.34). Far from prioritising 'opportunities for work', the majority cited 'learning a language' and 'experiencing culture' as the main motivations. Evans et al. (2015) found a similar pattern. A third of respondents had moved to London for, 'a life/cultural experience' and almost half had chosen the UK generally for the 'adventure/language/ culture/ quality of life' (p.18). Their answers seem to set them apart from other migrant groups in Carling and Jolivet's study. Regarding the Moroccans interviewed, most reported a financial benefit to living in the UK but felt that their 'quality of life' had deteriorated (2016, p.34). This article aims to expand on what the quantitative findings hint at, to explore the motivations and values of many Brazilian migrants in the capital. It argues that for many middle class Brazilians, the motivation to migrate is couched in terms of 'societal alienation' (Dashefsky \& Lazerwitz 1983): a feeling of distance from the place of origin resulting from a lack of identification and trust in its institutions and even the very culture of the place itself. This is in contrast to the concept of migrating due to 'material alienation' whose origins stem from 'commodity fetishism' (Marx 1867); migrating to access a higher level of material consumption or to acquire financial capital to use 'back home'. For those who migrate due to 'societal alienation' what is 'fetishised' is a less material interpretation of the 'quality of life' at the migration destination which becomes a kind of commodity in its own right. It argues that class divisions, which often intersect with regional and racial divisions within Brazilian society, are a key marker of difference in these two types of imaginary. This paper takes the following form: section one explains the theoretical 
framework. It first provides a working definition of 'middle class and goes on to explore the role of the geographical migration in free migration, and the two imaginings of the global north which inform the motivations for and experience of migration for those who choose to leave. Section two explores Brazilian migration to London and the geographical imagination examining how the idea of the geographical imagination can help us understand the desire to emigrate and where to immigrate to by focusing on the motivations for emigration from Brazil via an understanding of how London is imagined and experienced. It also examines how many middle class Brazilians imagine their migration project as distinct from the perceived transnational Brazilian 'community' in London who they seek to distinguish themselves from. It argues that they often position themselves as consumers of rather than producers of multiculturalism, in their imagined relationship to London as a multicultural world city

\section{Theoretical framework}

\subsection{Defining middle class and culture}

The term 'middle class' often means different things in different contexts (Gibson-Graham \& Ruccio 2001). In Brazil in particular, as Centner observes, "[t]he definition of "middle class" is imprecise and malleable' (2012, p.260) The Instituto Brasileiro de Geografia e Estatística (IBGE) [Brazilian Geography and Statistics Research Institute] uses multiples of the minimum wage to categorise the population in terms of social classes ranging from A - E. A more nuanced approach is taken by the Associação Brasileira das Empresas de Pesquisa (ABEP) [Brazilian Association of Research Companies] which measures class position not in terms of income but via levels of material consumption, and access to education and other public services (Kamakura \& Mazzon 2017). The 'C' class has been dubbed by researchers such as Neri (2011) as the 'new middle class'. These are often residents of what many from the Global North would consider to be 'favelas' [slums] but who have achieved a standard of consumption and income which leads them to be defined as middle class. It is worth noting that the definition of what constitutes a 'favela' in Brazil is itself extremely fluid and 
will change depending on who one asks (Cicalo 2012). Other scholars have pointed out weaknesses with Neri's claim of a 'new middle class'. Cardoso and Préteceille (2017) propose that, as well as income and consumption, it is also important to take into account occupational structure, and when one does so, a much smaller part of the $\mathrm{C}$ class should be called middle class. However, as well as objective measurements of class position it is important to include subjective measurements (Rubin et al. 2014). That many members of the C class self-define as middle class (Neri 2011; Neri 2014) should not be ignored then. What is clear is that the term 'middle class' can have a different connotation in Brazil than it may have in the UK and the fact that members of classes B and $\mathrm{C}$ will both self-define as 'middle class' despite the differences between them can be confusing to an outsider. This is because members of class B are typically using as a reference point, European or U.S. standards of living, education and position within the occupational structure. As a working definition then, when I refer to 'middle class Brazilians' I mean not only that they self-define as middle class but that they hail from the B class within the Brazilian classification system and that the material quality of their lifestyle, patterns of consumption, education levels and position within the occupational structure back in Brazil would be recognisable as 'middle class' by the standards of the Global North. The term 'lower middle class' can perhaps be used to describe the C class of Brazil who, despite also self-defining as middle class and having the ability to migrate to London, may not hold a position within the Brazilian occupational structure which would satisfy Cardoso and Préteceille's definition of middle class. Importantly, their income level may not be sufficient to be immune from experiencing 'material alienation' prompted by the globalised ideal of what constitutes middle class status which is informed largely by the standards and tastes of the Global North. Further, these class divisions often intersect with regional and racial divisions in Brazil. Middle class Brazilians, usually from the Southern and South-Eastern states and of largely Euro-Brazilian descent often find themselves working side by side, at least in the beginning of their time in London, with lower middle-class Brazilians from the poorer Central and North-Eastern states who are more likely to be of Indigenous and Afro-Brazilian descent. As a result, when many emphasise the distinctiveness, and individualistic nature of their migration motivations and experience, they are also emphasising class, regional and, often, racial divisions that characterise Brazilian society. 
As Thompson (2016) notes, although researchers frequently consider cultural factors when theorising migration decision making, this is usually in terms of the culture of origin. Either a culture of migration that exists in the origin country, or the attraction of migrating to a place that has similar cultural traits, like language or religion, to where one is from (Massey et al. 1993). What remains under-examined is the possibility of the culture of a migration destination acting as a 'pull' factor in migration decision-making and in the migration experience itself. This article uses the geographical imagination to explore the findings of my qualitative empirical work with predominantly middle-class Brazilian migrants living in London. It examines how these migrants imagine London and their place within it both before and after they arrive. Many of those I interviewed often maintain an ironic distance from the transnational Brazilian culture that is created 'by migrants for migrants' (Frangella 2010), which exists in London. I follow Sewell's (1999) definition of culture as both system and practice: as a set of practices that take place in the context of a semiotic system. Crang et al's (2003) concept of transnational culture as 'grounded' in a culture of material commodities helps make this more concrete. Rather than producers of an 'authentic' transnational Brazilian culture, here, many middle-class Brazilian migrants position themselves as consumers of wider transnational cultural commodities. They imagine themselves from the universalised perspective of one able to practice the consumption of (multi)cultural commodities with London imagined as the place, as the focus of the semiotic context or system, which provides this opportunity. Middle-class Brazilians are often more ambivalent in their relationship to national identity (Caproni 2014). As Marques de Souza (2013), in his essay on the Brazilian 'national' character observes:

The Brazilian characteristic... contains... an absence of a rigid bond, a bond that ends up being much more effective in the field of irony than in pride. Being Brazilian, it seems, is 'to not be a country'. It is to act through a synthesis that goes beyond these markings, for the sake of a third thing that is beyond what the idea of "country" can contain [translation mine] $(2013, \mathrm{p} .7)$.

This ambivalence towards national belonging can explain why many middle-class Brazilians distance themselves from Brazil both rhetorically, literally through the act of emigrating and in their social practices once they have migrated. Other researchers have found evidence of a tendency in the discourse 
and practice of many Brazilians to distance themselves from a supra national identity as 'LatinAmericans' (McIlwaine 2016, pp.174-175).

\section{2 'Free' migration and the geographical imagination}

For DellaPergola (1984), free migration, 'is associated with a very peculiar and narrow "space awareness"' (p.297) and certain goals, "can only be pursued in relation to a certain "ideal place"' (ibid.). Griffiths and Maile (2014) also assert that social imaginaries, 'are highly place specific' (p.156). The geographical imagination can help us understand why some places are attractive to migrants. As a working definition I follow Marcus (2009) who describes the geographical imagination as, 'the spatial knowledge - real or abstract - that allows individuals to imagine place'. The geographical imagination pertains to perceptions and experiences of place, and the behaviour and practices that occur within those places. Yet it is also a productive way of understanding how individuals imagine and negotiate their identities in relation to wider national and cultural ones (Gregory 1994). The geographical imagination is not just the understanding of space as the production of meaning attached to particular spaces, it is also used by individuals (and collectives) to negotiate their own sense of place and belonging within these imagined spaces. Although the geographical imagination can describe how people imagine the unfamiliar or 'exotic' (Said 1977), it is also useful to understand how the familiar, how the places of origin and to the aspects of the migration destination which are already familiar to migrants, yet not necessarily familiar in terms of dominant cultural practices at the place of origin, are imagined and, importantly, how the way the places of origin and destination are imagined, occur in reference to each other. What is imagined as 'unfamiliar' is often done so within a frame of reference of what is already familiar. The culture at the migration destination may be imagined as 'unfamiliar' and the desire to move there read as a kind of cosmopolitan desire for difference but it may also be imagined as 'familiar' through prior exposure to the semiotics of that culture via mediascapes (Appadurai 1996). Referring back to Sewell (1999) and Crang et al. (2003) then, it is possible to become familiar with 'unfamiliar' cultural commodities while feeling that one is unable to truly 'practice' the consumption of these cultural commodities without moving to a specific imagined place or semiotic context. Another key concept here is settlement identity (Feldman 1996), which can explain how the seemingly 'unfamiliar' 
is often imagined within a familiar context. In the same way that a desire for an unfamiliar soft drink still exists within the familiarity of the category 'soft drinks', so too can the desire to experience an unfamiliar city, be imagined within the familiarity of the category 'cities'. Finally, the geographical imagination emphasises how people imagine not only their migration destinations and what their lives will be like once there, but also the teleology of their migration. Benson and O'Reilly observe that, '[m]eanings and imaginings... have the power to shape reality because people act on them, not only by migrating but in the ways they live after migration' (2016, p.11). Thus, the way in which migrants imagine their migration project shapes the reality of their lived experience at the destination.

\subsection{Material and societal alienation: modernist and post-modernist imaginings of the West}

As Marx (1867) observed, modernism is characterised by the fetishisation of material objects. Commodities can transcend their straight-forward 'use-value' and be reified to take on almost mystical properties. Wang (1998) in her comparison of U.S. and Chinese culture focuses on modernist capitalist values as a key demarcation. She writes,

'While the Chinese value 'order' and 'harmony', the American emphasis is rather on material accumulation......American ideology defines the 'good life' in terms of a high standard of living and possession of an abundance of material goods (p.43).

Applied to migration theory then, migrants are exposed, via mediascapes (Appadurai 1996) to a consumption led lifestyle that they are unable to attain in their home country resulting in a kind of 'material alienation', prompting a desire to migrate. As Portes and DeWind (2004) explain, 'the forces of capitalist globalization... expose and entice Third World populations to the benefits of modern consumption, while denying them the means to acquire them (p.831). This understanding of international migration can thus be termed 'modernist' since material consumption is a key motivation to migrate. However, what this cannot account for is why those, whose material comfort in their home countries is already at a comparable level with the Global North, can still feel a sense of alienation or distance from their origin society and desire to emigrate. Dashefsky and Lazerwitz (1983) refer to this as 'societal alienation'. Here migrants do not necessarily imagine their destination in terms of material 
benefits but societal or cultural ones. This echoes Carling and Jolivet's statement that, in contrast to other nationalities they interviewed, the Brazilians 'tend[ed] to be more satisfied with the quality-oflife impacts of migration than with the financial benefit' (2016, p.39). For many middle class Brazilians, what makes London an attractive migration destination, and Brazil an unattractive place to remain, is not only the possibility to consume or practice the material aspects of what they imagine as London's culture, but also the immaterial aspects which too become commodified.

\section{Brazilian migration and the geographical imagination}

A 'modernist' understanding of migration motivations illuminates how the West, imagined in terms of the material can still be compatible with the values and culture of the country of origin. As Hannerz observes:

[F]or many 'labour' migrants, 'going away may be, ideally, home plus higher income; often the involvement with another culture is not a fringe benefit but a necessary cost. A surrogate home is created with the help of compatriots, in whose circle one feels most comfortable' (1990, p.248).

Dias' (2009) work on 'semi-documented', typically lower middle class Brazilian migrants in London provides further insight. He reports that his subjects viewed London's public spaces as unfamiliar and even hostile due to linguistic and cultural barriers. Their priority then was to (re) create a transnational support network within London as a kind of psychic defence against the unfamiliar. He writes, 'for the Brazilian immigrant, [even] leisure is not essentially linked to the enjoyment of the English culture or the universal culture that the city offers' (p.44). Instead their leisure time is spent engaging with what Frangella (2010) and Brightwell (2012) have identified as an 'economy of saudade [homesickness/longing]': a network of restaurants, cafés, bars and social events created by and for Brazilian immigrants themselves. The unfamiliar cultural, geographic and linguistic aspects of London are imagined as a barrier in the discourse of Dias' subjects. Their ultimate goal was to earn and save money and return to Brazil. As one migrant put it, 'I do not care how flexible I need to be. The more I work here' the sooner I can return to my home and my family' [translation mine] (p.23). But what of 
those who migrate precisely because of the desire to experience what they imagine as unfamiliar? Many of my interviewees decided to move to London despite coming from relatively wealthy backgrounds with established careers. When asked about their motivations to migrate, they often highlighted factors relating to societal rather than material alienation. Frustration with corruption, inequality and in fact, the entire culture itself were often mentioned. Carla, had been living in São Paulo before moving to London. Despite having a successful career there, she cited the extreme inequality as a major reason for her feeling alienated from the city:

I had a really good salary there. And I couldn't stand that the people who worked with me, the kitchen porter, how does he live...? I know it's cowardly [to leave] but I couldn't stand this.. [I]n São Paulo, seeing people in the [bus] queues. I had money to take a taxi but they don't and I think this is the most heart breaking thing in Brazil. If everybody's poor ok everybody's poor what can you do. But... São Paulo has the biggest amount of helicopters, they have [helicopter] traffic! (Interview, in English, London, 31.05.17)

Carla had moved with her husband Fernando, a native from São Paulo. He stated that he had come to feel like a 'fish out of water' [um peixe fora da agua] there, despite having achieved a successful career:

I was born in São Paulo, in that rush... And as time passed I began to realize that I did not like to live [there] anymore... That my business was in a smaller city... where time passes more slowly... You take more advantage of nature... And São Paulo has changed a lot... The city's growing disorganized, growing more than it can withstand... So much has changed for the worse ... it was like... What am I doing here?" (Interview, in Portuguese, London, 20/07/17)

Fernando's imagining of London as a more 'intimate' and less hectic place to live can be understood in reference to Feldman's (1996) concept of 'settlement identity'. People often identify with a type settlement and so migrate to similar places as a way to maintain a sense of place attachment and selfidentity. An actor's imagining of what constitutes 'difference' often takes place within the context of what is already familiar. Within the framework of the type of settlement that $\mathrm{F}$ has grown to identify with (large urban centres), London is imagined as a less stressful alternative to São Paulo. Fernando 
imagines a 'different' pace of life then, within the context of the familiarity of the pace of large urban centres. For other interviewees their dissatisfaction was more far reaching. Take Catarina, another São Paulo native, who left a well-paid career and comfortable material quality of life because she too felt unsatisfied. Her sense of alienation extended into the very culture of the country. She explained:

I lived in São Paulo and did not have such a bad life. I had a house I had a car but..... the country has this jeitinho brasileiro [Brazilian way of bending the rules]..., it's something that annoys me about Brazilians... you find it there in public services... the government, they do not care ... I never liked anything... not even the food! I never really liked the music too.

Interviewer: You don't like Brazilian music? So all your life you were listening to? Catarina: Music from here, bands from the United States. Maybe because of that I have always had the will to see things like that. (Interview in Portuguese , London, 22.06.17).

Here, via exposure to mediascapes generated from the UK, Catarina had come to identify with certain cultural semiotics over and above those of her place of origin. Her desire to migrate then can in part be understood as a desire to practice the cultural 'language' (Sewell 1999) she had learnt prior to migrating to where she imagined the source of this 'language' to be. Thompson (2016) recorded a similar phenomenon. Her research into Filipino emigration showed that those who identified more with, 'anime, K- Pop and gaming (dominant forms of Asian pop culture) generally aspired to migrate to destinations within Asia' whereas Filipinos, 'who primarily engaged with US and British pop culture... aspired to move to 'the West' (p. 4). These examples demonstrate the importance of taking into account how migrants imagine and can thus identify with the cultural, as well as social and economic aspects, of their preferred migration destinations.

\subsection{Cosmopolitanism and class 'othering'}

As Horst et al. (2016) have noted middle class Brazilians are often imagine their migration in individualistic terms (p.102). Many of their interviewees stressed their distinctiveness from 'those other Brazilians' who do not interact with the 'host' society. Martins Jr. also found that: 
[M]iddle-class Brazilians... reproduce class differences... by constructing and distancing their 'cosmopolitan experience' from... 'the community', as well as those of 'the Brazilian (economic) migrant' (2017, p.176)

This distancing from 'economic' or labour migrants often appeared in the discourse of my interviewees. Bruno, originally from São Paulo remarked on the 'other Brazilians' thus:

Well most of the people come here to make money for the jobs.... So they come here because of this but I think they're missing their life in Brazil so they try to find this life here... I prefer to do things differently (Interview, in Portuguese, London, 10.06.17).

Vlad, originally form Porto Alegre, expanded this sentiment:

I am here because I always want to learn something different. If I speak Portuguese, go to a Brazilian concert, I'm not learning. I would swap that for a Japanese concert. I have a lot more to learn from that than everything I already know from my country (Interview, in English, London, 12.05.17).

Laura from São Paulo, had this to say about the Brazilian leisure events in London:

Laura: I don't go to Brazilian parties no.

Interviewer: Why not?

Laura: I don't like, I'm gonna be a bit race... not racist but most of the Brazilians here are not really my type of Brazilian (Interview, in English, London, 30.05.17).

Laura's answer shows how class divides in Brazil often intersect with racial and regional divides. This is especially so since many who are able to travel to the UK on an ancestral EU passport have partly or entirely European descent and are able to use these passports as a material enabler of their ability to imagine their migration as motivated by cultural or lifestyle reasons rather than from economic hardship. The geographical divides between the poorer Central, and North-Eastern states and the richer Southern and South-Eastern ones can often serve as place holders for race and class differences. However, many of those I interviewed from the wealthier Brazilian states who were of Afro or Indigenous descent often demonstrated the same distancing towards those from poorer states. At 
times, it seemed that their regional identity took precedence over a racial identity. Take for example Caetano from São Paulo who described himself as 'three quarters black and a quarter Portuguese'. He viewed his own migration as a kind of adventure or cultural experience and assessed what he considered as labour migrants from the poorer state of Goiás thus:

Yeah, there are many people from Goiania... like the centre of Brazil. We Brazilians, we don't trust them. They are all leeches...Different kind of Brazilian (Interview, in English, 4/7/17).

Many interviewees were ambivalent towards the transnational Brazilian places and cultural practices in London instead imagining their experience in more cosmopolitan terms. London was viewed as embodying in space, a multicultural, post-national or anational ideal. The culture that many interviewees wished to experience was not transnational Brazilian culture, in fact it was not specific to any one country or nationality but, more accurately, specific to a London imagined as a world city. It is within this multicultural paradigm that many of them articulated a sense of belonging; of feeling that they 'fit in'. This sense of belonging was often made more apparent upon leaving London as Luciana explains:

I noticed there wasn't a lot of non-white faces around. And this is very strange if you live in London... So I think for the first time I really felt out of ... I felt I'm in Britain. I'm not in an international city. Because here I don't feel different from other people, but there for the first time I really did. It was like, okay, I am out of my element here. I am the stranger (Interview, in English, 12.05.17).

As one of the interviewees from the THEMIS project (Carling \& Jolivet 2016) put it, 'I can live in London, but I cannot live in England' (Interview with Alvaro, London, 2011). In other words, many do not imagine London as an opportunity to immerse themselves in English or British culture so much as to experience what they understand as 'London' culture, which they unanimously define as multicultural. Yet they do not view themselves as forming the 'authentic' transnational manifestation of a Brazilian culture in London. Rather they often see themselves from the universalised perspective 
of one able to appreciate multiculturalism as consumers of an anational multiculturalism rather than its 'authentic' producers.

\section{Conclusion}

This paper used the quantitative findings described by Evans at al. (2015) and Carling and Jolivet (2016) to explore the motivations for migration amongst middle class Brazilians living in London. It juxtaposed two modes of alienation: material and societal. Material alienation was understood as stemming from an unfulfilled desire for higher levels of consumption and financial accumulation. This mode of alienation can act as a motivation to migrate exclusive from any identification with the cultural practices at the migration destination. Societal alienation hinges on the idea that the culture at the migration destination can act as a draw itself, and is often contrasted to the culture at the place of origin. These two modes of imagining migration destinations often intersect with differences in social class which in turn may relate to racial and regional divisions. Those who already have their material needs or desires satisfied are unlikely to migrate due to 'material alienation'. Instead, they are more likely to frame their desire to migrate in terms of 'societal alienation'. Throughout, this paper referred to the concept of the geographical imagination to argue that, for many middle class migrants then, it seems that 'quality of life' and 'cultural experiences' are the primary stated impetuses for migration over financial accumulation. The paper ended by drawing on data from qualitative interviews with middle class Brazilians living in Sao Paulo. For many, 'quality of life' was couched in terms of imagining London as a place with more equality, a less hectic and more intimate pace of life than Sao Paulo and as a place to consume cultural commodities and participate in cultural practices that do not originate from Brazil. These 'pull' factors are attractive independent of any potential drop in financial or social status that may arise because of migrating. Ultimately, although cultural motivations to migrate have long been acknowledged, this article hopes to have demonstrated that, a migrant's imagined relationship to the existing culture at the migration destination is an important factor to consider. London, imagined as a multicultural world city, can have different connotations and produce different subjective experiences dependent on how migrants imagine their relationship to and place within it. This article also shows that we should problematise the concept of transnational 
'communities' defined by national origin. It reveals the class based, regional and often racial, divisions within these groups since the way many imagine their identity and place within the city is often achieved via a distancing in both discourse and cultural practice from what is framed as 'lower class' labour migrants.

Acknowledgements:

With thanks to members of GOSSIP (Geographies of Sustainability, Society, Inequalities and Possibilities) for feedback on earlier drafts of this paper.

\section{References}

Appadurai, A., (1996). Modernity at Large: Cultural Dimensions of Globalisation, Minneapolis: University of Minnesota Press.

Brightwell, M. das G., (2012). On the Move and in the Making: Brazilian Culinary Cultures in London. Canadian Journal of Latin American and Caribbean Studies, 37(74), pp.51-81.

Caproni, L., (2014). O Complexo de Vira-latas, Brazil: Cabrueira Filmes \& Sem Cortes Filmes.

Cardoso, A. \& Préteceille, E., (2017). Classes Médias no Brasil: Do que se Trata? Qual seu Tamanho? Como Vem Mudando? Dados, 60(4), pp.977-1023. Available at: http://www.scielo.br/scielo.php?script=sci_arttext\&pid=S0011$52582017000400977 \& \operatorname{lng}=$ pt\&tlng $=$ pt.

Carling, J. \& Jolivet, D., (2016). Exploring 12 Migration Corridors: Rationale, Methodology and Overview. In O. Bakewell et al., eds. Beyond Networks: Feedback in International Migration. London: Palgrave Macmillan, pp. 18-46.

Centner, R., (2012). Distinguishing the right kind of city: contentious urban middle classes in Argentina, Brazil, and Turkey. In T. Roshan Samara et al., eds. Locating Right to the City in the 
Global South. London: Routledge, pp. 260-76.

Cicalo, A., (2012). Urban Encounters Affirmative Action and Black Identities in Brazil, New York: Palgrave Macmillan US.

Crang, P. et al., (2003). Transnationalism and the spaces of commodity culture. Progress in Human Geography, 4, pp.438-56.

Dashefsky, A. \& Lazerwitz, B., (1983). The Role of Religious Identification in North American Migration to Israel. Society for the Scientific Study of Religion, 22(3), pp.263-75.

DellaPergola, S., (1984). On the Differential Frequency of Western Migration to Israel. Studies in Contemporary Jewry, 1, pp.292-315.

Dias, G.T., (2009). O processo de fixação do migrante brasileiro em Londres: a importancia das práticas cotidianas na elaboração de sua identidade. Ponto Urbe, pp.1-15.

Evans, Y. et al., (2015). Diversidade de Oportunidades: Brasileiras no Reino Unido, 2013 -2014, London.

Feldman, R.M., (1996). Constancy and Change in Attachments to Types of Settlements. Environment and Behavior, 28(4), pp.419-45. Available at: http://journals.sagepub.com/doi/10.1177/0013916596284001 [Accessed November 30, 2017].

Frangella, S., (2010). O Made in Brasil em Londres: migração e os bens culturais. Travessia - revista do migrante, 66, pp.33-44.

Gibson-Graham, J. \& Ruccio, D., (2001). After Development: re-imagining economy and class. In J. Gibson-Graham et al., eds. Re/presenting class: Essays in postmodern Marxism. Duke University Press, pp. 158-81. Available at: https://books.google.co.uk/books?hl=en\&lr=\&id=MXRqWvNGk0AC\&oi=fnd\&pg=PA1\&dq=gi bson+graham + re/presenting + class\&ots $=218 \mathrm{QTtv} 8 \mathrm{SD} \&$ sig $=1 v N v M n 0 \mathrm{Bm} 0 \mathrm{jEV}$ O_W4s2PKcbL90 [Accessed December 15, 2017]. 
Gregory, D., (1994). Geographical Imaginations Blackwell., Cambridge, MA.

Griffiths, D. \& Maile, S., (2014). Britons in Berlin: Imagined Cityscapes, Affective Encounters and the Cultivation of the Self. In M. Benson \& N. Osbaldiston, eds. Understanding Lifestyle Migration: Theoretical Approaches to Migration and the Quest for a Better Way of Life. Basingstoke, UK: Palgrave Macmillan, pp. 211-34.

Hannerz, U., (1990). Cosmopolitans and Locals in World Culture. Theory, Culture \& Society, 7(2-3), pp.237-51. Available at: http://journals.sagepub.com/doi/10.1177/026327690007002014 [Accessed February 27, 2018].

Horst, C. et al., (2016). The Impact of Class on Feedback Mechanisms: Brazilian Migration to Norway, Portugal and the United Kingdom. In O. Bakewell et al., eds. Beyond Networks: Feedback in International Migration. London: Palgrave Macmillan.

Kamakura, W. \& Mazzon, J., (2017). Estratificacao Socioeconomica e Consumo No Brasil, Sao Paulo: Blucher.

Marques de Souza, M., (2013). O complexo de vira-lata e o vira-lata complexo. TRANZ - revista de uma publicação de estudos transitivos do contemporâneo, 8(December), pp.1-5. Available at: http://www.tranz.org.br/8_edicao/TranZ13-Marcelo-Formatado.pdf [Accessed July 12, 2017].

Martins Junior, A., (2017). The production and negotiation of difference in a world on the move: Brazilian migration to London. Goldsmiths University. Available at: http://research.gold.ac.uk/20120/1/SOC_thesis_MartinsJuniorA_2017.pdf.

Marx, K., (1867). Capital: a Critique of Political Economy, Vol. 1: the Process of Production of Capital. marxists.org. Available at: https://www.marxists.org/archive/marx/works/download/pdf/Capital-Volume-I.pdf [Accessed February 8, 2017].

McIlwaine, C., (2016). Latin London: Negotiating Invisibility among Latin Americans in London. In A. Kershen, ed. London the Promised Land Revisited The Changing Face of the London 
Migrant Landscape in the Early 21st Century. London: Routledge, pp. 167-87.

Neri, M., (2011). A Nova Classe Média: o lado brilhante da base da pirâmide, São Paulo: Saraiva.

Neri, M., (2008). A Nova Classe Média. Available at: http://www.cps.fgv.br/ibrecps/M3/M3_TextoFinal.pdf.

Neri, M.C., (2014). Brazil's Middle Classes, Rio de Janeiro. Available at: http://hdl.handle.net/10438/12988 [Accessed May 22, 2018].

Rubin, M. et al., (2014). "I Am Working-Class": Subjective Self-Definition as a Missing Measure of Social Class and Socioeconomic Status in Higher Education Research. Educational Researcher, 43(4), pp.196-200. Available at: http://edr.sagepub.com/cgi/doi/10.3102/0013189X14528373.

Said, E., (1977). Orientalism, London: Penguin.

Sewell, W., (1999). The Concept(s) of Culture. In V. Bonnell \& L. Hunt, eds. Beyond the cultural turn: new directions in the study of society and culture. Oakland, CA, USA: University of California Press, pp. 35-61.

Thompson, M., (2016). Migration Decision-Making: a Geographical Imaginations Approach. Area. Available at: http://doi.wiley.com/10.1111/area.12292.

Wang, W., (1998). Can Ideology-Shift be a Determinant of International Migration? A Case Study of Professional Migration from China to the USA. International Review of Modern Sociology, 28(1), pp.37-58. Available at: http://www.jstor.org/stable/41421631. 